\title{
PENGEMBANGAN MULTIMEDIA PEMBELAJARAN INTERAKTIF MENGGUNAKAN TRANSISI MORPH DAN ZOOM MATERI PERBANDINGAN
}

\author{
Yunita Istianah $^{1}$, Iskandar Wiryokusumo ${ }^{2}$, Ibut Priono Leksono ${ }^{3}$ \\ 1,2,3Program Pascasarjana, Universitas PGRI Adi Buana Surabaya \\ email: yunitaistiana@gmail.com \\ email: wiryokusumoiskandar@gmail.com \\ email: ibutpriono@unipasby.ac.id
}

\begin{abstract}
In facing an industrial revolution 4.0, teachers have to make an affective education technology. One of that is using multimedia-based interactive media with power points. The aims of this study is to describe the development of interactive multimedia using Microsoft Office 365 Power Point by utilizing the morph and zoom transition features as interactive multimedia. This study uses the ADDIE development model with Luther's multimedia development theory design which is based on six steps as concept, design, material collection, manufacturing, testing, and dissemination. The trials were conducted with expert trials, peer trials and small group trials. The small group trial subjects consisted of 12 grade VII students of SMP Negeri 55 Surabaya. The instrument that used was in the form of an expert trial sheet, peers and a product of eligibility questionnaire for students. The results of product development from the material expert test results obtained 97\%, while the media expert test results obtained $78.1 \%$, and for peer testing the results obtained $95 \%$. The result percentage of the feasibility questionnaire test data was $81.33 \%$, it was included in the excellent category. So, this interactive learning multimedia is appropriate to be used in support the learning activities of VII grade students of SMP Negeri 55 Surabaya.
\end{abstract}

Keywords: development, multimedia interactive learning, Microsoft office 365, PowerPoint, mathematics

\begin{abstract}
Abstrak: Dalam menghadapi revolusi industri 4.0, guru harus membuat sebuah teknologi pembelajaran yang efektif. salah satunya menggunakan media interaktif berbasis multimedia dengan powerpoint. Tujuan penelitian ini adalah mendeskripsikan pengembangan mutlimedia interaktif menggunakan microsoft office 365 power point dengan memanfaatkan fitur transisi morph dan zoom untuk dijadikan multimedia interaktif. Penelitian ini menggunakan model pengembangan ADDIE dengan desain teori pengembangan multimedia Luther yang dilakukan berdasarkan enam langkah yaitu konsep, desain, pengumpulan bahan, pembuatan, uji coba, penyebarluasan. Uji coba yang dilakukan menggunakan uji coba ahli, uji coba teman sejawat dan uji kelompok kecil. Subjek uji coba kelompok kecil terdiri dari 12 peserta didik kelas VII SMP Negeri 55 Surabaya. Instrumen yang digunakan berupa lembar uji coba ahli, teman sejawat dan angket kelayakan produk untuk peserta didik. Hasil pengembangan produk dari data hasil uji coba ahli materi diperoleh persentase sebesar 97\%, sedangkan uji coba ahli media diperoleh hasil persentase sebesar 78,1\%, dan untuk uji coba teman sejawat diperoleh hasil persentase sebesar 95\%. Persentase hasil data uji angket kelayakan sebesar 81,33\%, angka tersebut masuk dalam kategori sangat baik. Sehingga multimedia pembelajaran interaktif ini layak digunakan untuk mendukung kegiatan pembelajaran peserta didik kelas VII SMP Negeri 55 Surabaya.
\end{abstract}

Kata Kunci: pengembangan, multimedia pembelajaran interaktif, Microsoft office 365, PowerPoint, matematika 


\section{PENDAHULUAN}

Dunia pendidikan saat ini sedang dihebohkan dengan revolusi industri 4.0, di mana semua ranah pendidikan sudah menggunakan teknologi, hal ini menuntut semua guru untuk lebih aktif dan tidak buta teknologi, setiap guru dituntut untuk meningkatkan kreativitasnya dalam menyampaikan materi di dalam kelas. Penggunaan teknologi menurut Mayasari, Hasanudin, \& Fitrianingsih (2020) mendorong manusia untuk lebih memiliki skill dan kompetensi yang baik diberbagai bidang profesi.

Untuk menunjang hal tersebut, pemerintah mengadakan pelatihanpelatihan ataupun diklat untuk guru-guru dalam menyongsong revolusi industri 4.0. Pelatihan yang dilaksanakan diperuntukkan kepada seluruh guru bidang apapun dapat berpartisipasi termasuk guru matematika.

Matematika tidak sebatas pelajaran perhitungan namun matematika juga merupakan pengetahuan yang ada di sekitar kita, saat matematika diimplementasikan dalam kehidupan sehari-hari, pola berpikir akan lebih rasional dan kritis karena masalah yang ada dianggap fakta. Suherman (2003) juga mengatakan bahwa matematika merupakan Bahasa yang menggunakan istilah yang didefinisikan dengan cermat, jelas, dan akurat, representasinya dengan simbol dan padat, lebih berupa Bahasa simbol mengenai ide dari pada mengenai bunyi. Sebagai seorang pendidik cita-cita terbesar dalam dunia pendidikan adalah mencerdaskan anak bangsa.

Sistem pendidikan nasional menurut UUD No. 20 Tahun 2003 pasal 3 berfungsi untuk mengembangkan potensi peserta didik menjadi insan yang beriman dan bertakwa, berakhlak mulia, sehat, berilmu, cerdas, kreatif dan mandiri, demokratis dan bertanggungjawab. Peserta didik tahun 2000-an lebih tertarik dengan penyampaian materi yang kreatif dan kekinian karena mereka generasi millenial atau generasi $\mathrm{Z}$ di mana generasi dengan teknologi yang semakin berkembang, untuk menciptakan suasana kelas yang asyik dan menyenangkan salah satunya dengan membuat media pembelajaran interaktif berbasis multimedia berupa slide show powerpoint.

Penelitian ini dilakukan untuk menjawab kesenjangan antara harapan dan kenyataan yang ada dalam penyampaian materi yang kurang menarik dan monoton penuh dengan tulisan. Saat ini powerpoint seperti media yang tidak menarik karena kurangnya minat guru atau tenaga pendidik untuk belajar dan lebih kreatif dalam menyajikan materi bentuk powerpoint. Pentingnya pengembangan multimedia interaktif ini adalah meninggalkan momok powerpoint yang membosankan dan monoton penuh dengan tulisan. Sehingga, Powerpoint dapat dikemas dengan sebaik dan semenarik mungkin.

Degeng (2018) Media pembelajaran adalah komponen strategi penyampaian yang dapat dimuati pesan yang akan disampaikan kepada si belajar, apakah itu orang, alat, atau bahan. Martin dan Briggs dalam Degeng (2018) Media pembelajaran mencakup semua sumber yang diperlukan untuk melakukan komunikasi denga si belajar. Media pembelajaran menurut Suartama (2012) adalah segala sesuatu yang dapat digunakan untuk menyalurkan pesan dari pengirim ke penerima pesan sehinggga dapat merangsang pkiran, perasaan, perhatian dan minat siswa sedemikian rupa sehingga proses belajar terjadi. Media menurut Hasanudin, (2017) adalah penyalur pesan yang dapat merangsang perhatian siswa dalam proses pembelajaran. Media pembelajaran menurut Brata (2020) dapat menyajikan praktik kearifan lokal yang dapat digunakan sebagai strategi.

Sekurang-kurangnya ada lima strategi/cara dalam mengklasifikasi media pembelajaran untuk keperluan mempreskripsikan strategi penyampaian 1) tingkat kecermatan representasi, 2) tingkat interaktif yang mampu ditimbulkannya, 3) tingkat ke-mampuan khusus yang dimilikinya, 4) tingkat motivasi yang mampu ditimbulkan-nya, dan 5) tingkat biaya yang diperlukan. Penelitian pengembangan ini lebih memfokuskan pada pengembangan media pembelajaran interaktif berbasis multimedia

Salah satu media pembelajaran yang memanfaatkan teknologi informasi dan 
komunikasi dalam pembelajaran yang dapat memotivasi siswa dalam belajar adalah multimedia pembelajaran interaktif menggunakan powerpoint.

Multimedia Menurut Arsyad (2002) adalah berbagai macam kombinasi grafik, teks, suara, video, animasi. Daryanto (2013) Menyatakan bahwa, kelebihan multimedia pembelajaran, yaitu: (1) menyaksikan benda atau peristiwa pada masa lampau seperti sebuah gambar, slide, film video atau media lainnya, sehingga peserta didik dapat memperoleh gambaran yang nyata tentang benda atau peristiwa sejarah; (2) memperoleh gambar yang jelas tentang benda/ hal-hal yang sukar diamati secara langsung karena ukurannya yang tidak memungkinkan, baik karena terlalu besar atau terlalu kecil seperti skala pada peta pulau Kalimantan; (3) dengan mudah membandingkan sesuatu dengan bantuan gambar, model atau foto yang dapat dengan mudah membandingkan dua benda yang berbeda sifat, ukuran, warna dan sebagainya; (4) mengamati Gerakangerakan mesin/ alat yang sukar diamati secara langsung dengan menggunakan film video sehingga memudahkan peserta didik mengamati jalannya mesin speedometer pada motor untuk menghitung kecepatan dan jarak; dan lain-lainnya.

Robin dan Linda dalam Darmawan (2017) Menyebutkan multimedia sebagai alat yang dapat menciptakan presentasi yang dinamis dan interaktif mengombinasikan teks, grafik, animasi, audio, dan video. (Hofsteder dalam Darmawan, 2017: 32) menyebutkan bahwa multimedia dapat dipandang sebagai suatu pemanfaatan komputer untuk membuat dan meng-gabungkan teks, grafik, audio, gambar bergerak (video dan animasi) dengan meng-gabungkan link dan tool yang memungkin-kan pemakai untuk melakukan navigasi, berinteraksi, berkreasi, dan berkomunikasi. Menurut Darmawan (2017) adapun karakteristik sebuah pembelajaran dapat dikatakan meng-gunakan multimedia, yaitu yang pertama jika memiliki content representation, full color and high resolution, melalui media elektronik, tipetipe pembelajaran yang bervariasi, respons pembelajaran dan penguatan, mengembang- kan prinsip self evaluation dan digunakan secara klasikal atau individual. Sedangkan sebuah multimedia dapat dikatakan interaktif harus memiliki karakteristik seperti komunikasi dua arah, aktivitas fisik dan mental, feedback langsung, drag and drop, input data, mouse klik, mouse enter, selection, drawing, masking.

Pengembangan ini berfokus kepada tingkat interaktif yang mampu ditimbulkan oleh media yang dikembangkan, karena media yang ingin dikembangkan adalah multimedia interaktif, bukan berarti pengembang menghilangkan komponen lainnya, yang lain masih diperlukan dalam mengklasifikasi multimedia pembelajaran. Tingkat interaksi yang mampu ditimbulkan oleh suatu media juga dapat dibentangkan dalam suatu kontinum, tetapi titik-titik dalam kontinum ini ditunjukkan oleh jenis media yang berbeda: komputer, guru, buku kerja, buku teks/ rekaman, dan siaran radio/ televise (Degeng, 2018). Interaksi media memang komponen kedua dalam mempreskripsikan strategi penyampaian, Degeng (2018) interaksi siswa dengan media inilah yang sebenarnya merupakan wujud nyata dari tindak belajar.

Berdasarkan penelitian Kustianah, Mustaji, \& Walujo (2019) bahwa perangkat pembelajaran matematika berbasis multimedia dinyatakan layak sehingga membantu peserta didik untuk belajar secara mandiri. Kemudian menurut Susilo, Degeng, \& Susilaningsih (2017) bahwa multimedia interaktif yang dikembangkan valid sebagai media pembelajaran IPA untuk siswa kelas $\mathrm{V}$ pokok bahasan organ tubuh manusia dan hewan. Hasil penelitian Yusuf, Toenlioe, \& Wedi (2017) bahwa multimedia pembelajaran interaktif yang dikembangkan valid dan efektif untuk digunakan dalam pembelajaran. Menurut Astari, Tastra, \& Sudhita (2016) terdapat perbedaan yang signifikan hasil belajar antara siswa yang menggunakan dengan siswa yang tidak menggunakan multimedia presentasi pembelajaran pada pelajaran IPA.

Pengembang membuat penelitian pengembangan yang berbeda dengan menggunakan transisi morph dan zoom pada microsoft office 365 pelajaran 
matematika materi perbandingan. Pengembangan multimedia ini menggunakan perangkat lunak microsoft office 365 power point. Pada tahun 2019 microsoft office mengeluarkan versi terbaru dari office 365 proplus ke microsoft office 365 dan melakukan pembaruan pada sistemnya, terdapat beberapa fitur yang dikeluarkan microsoft office 365 powerpoint yaitu transisi morph dan zoom. Animasi yang dibuat tanpa batas di setiap urutan slide dengan menggunakan transisi morph dan akan terlihat bahwa slide presentasi yang ditampilkan layaknya sebuah video yang dibuat dengan software edit video.

Penggunaan secara teknis sederhana seperti penggunaan transisi lainnya, namun efek yang dihasilkan sangat luar biasa. Sedangkan dengan fitur zoom dapat menautkan bagian-bagian yang berbeda dari slideshow maksudnya fitur zoom dapat beralih dari slide 5 ke slide 8 atau slide lainnya. Memanfaatkan berbagai fitur baru dari microsoft powerpoint tentu akan menghasilkan media interaktif berupa slide show power point berbasis multimedia yang berbeda dan lebih menarik dan terlihat seperti media video, jika sebelumnya hanya berisi kumpulan materi yang penuh dengan tulisan, desain slide atau transisi yang biasa saja kini dengan memanfaatkan fitur transisi morph dan zoom akan membuat tampilan berbeda dari multimedia yang digunakan sebelumnya dan tentunya juga lebih interaktif, kreatif dan menarik. Selain hal di atas, sempat beredar kabar bahwa powerpoint tidak efektif digunakan dalam pembelajaran karena powerpoint yang disajikan kurang menarik, bahkan bukan berisi poin-poin, dan lainnya yang harus disajikan dengan baik menggunakan aplikasi sejenis powerpoint.

Berdasarkan latar permasalahan di atas, untuk menjawab permasalahan yang ada maka produk yang dihasilkan berupa multimedia interaktif menggunakan fitur microsoft office 365 power point yaitu dengan transisi morph dan zoom. Selain morph dan zoom, dilakukan juga kombinasi dengan animasi, gambar, bentuk atau fitur lain di dalam multimedia pembelajaran yang dibuat. Terdapat juga soal-soal yang interaktif untuk memperdalam pemahaman peserta didik. Spesifikasi produk pengembangan multimedia interaktif, terdapat tombol navigasi yang dapat terhubung dengan semua tampilan slide, materi yang disajikan mata pelajaran matematika bab Perbandingan, terdapat ilustrasi gambar dan video terkait materi perbandingan, latihan soal dapat membuat siswa terbiasa dengan soal-soal perbandingan, kuis untuk evaluasi materi perbandingan yang berupa soal pilihan ganda, terdapat bahan ajar berupa buku paket untuk siswa pelajari di rumah, serta buku panduan untuk mengetahui cara pemakaian produk pengembangan multimedia.

Pengembangan ini dilakukan pada mata pelajaran matematika kelas VII. Materi perbandingan sangat cocok untuk dibuat multimedia karena pada materi ini banyak persoalan berupa soal cerita sehingga dalam penyelesaiannya membutuhkan ilustrasi yang memudahkan peserta didik menyelesaikan soal-soal cerita yang tersedia. Kedudukan media pembelajaran dalam pembelajaran matematika sebagai salah satu upaya untuk mempertinggi proses interaksi guru-siswa dan interaksi siswa dan lingkungan belajar matematika. Fungsi media pembelajaran adalah sebagai alat bantu mengajar, yakni menunjang penggunaan metode mengajar yang dipergunakan guru (Istiqlal, 2017).

Peserta didik kelas VII SMP Negeri 55 Surabaya kurang baik dalam mengilustrasikan soal cerita matematika, sehingga pengembangan multimedia ini sangat dibutuhkan oleh mereka untuk memudahkan melakukan penyelesaian soal cerita. SMP Negeri 55 Surabaya terletak di tengah perkampungan masyarakat, sangat penting untuk menggunakan multimedia yang menarik dan menerapkan teknologi dengan baik, agar dapat bersaing dengan sekolah lain yang berada di tengah kota.

\section{METODE PENELITIAN}

$$
\begin{aligned}
& \text { Model pengembangan dalam } \\
& \text { penelitian ini menggunakan model } \\
& \text { pengembangan ADDIE dengan desain teori } \\
& \text { model pengembangan multimedia } \\
& \text { LUTHER. Hal ini karena desain Luther }
\end{aligned}
$$


sangat cocok digunakan dalam pengembangan multimedia ini, pembahasan yang dijelaskan sangat berhubungan. (Luther dalam Binanto, 2010: 259) menyatakan bahwa pengembangan sistem multimedia dilakukan berdasarkan enam langkah yaitu concept (konsep), design (desain), material collecting (pengumpulan bahan), assembly (pembuatan), testing (uji coba), dan distribution (distribusi). Berikut gambar dari desain Luther.

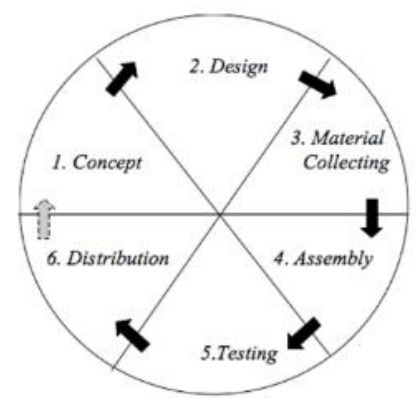

Gambar 1. Desain Luther

(Sumber: Luther dalam 2010)

Adapun langkah yang dilakukan oleh pengembang sesuai dengan langkahlangkah Luther, yaitu:

\section{Konsep}

Langkah ini dilakukan untuk menentukan mata pelajaran, merumuskan kompetensi dasar, dan menentukan konsep multimedia pembelajaran. Mata pelajaran yang akan dikembangkan adalah mata pelajaran Matematika SMP kelas VII materi Perbandingan.

\section{Desain}

Pada langkah ini pengembang membuat spesifikasi secara rinci mengenai arsitektur proyek, serta gaya dan kebutuhan material untuk proyek spesifikasi yang dibuat berdasarkan pada perancangan materi yang dimasukkan dalam multimedia pembelajaran, dan state diagram untuk menggambarkan alur kontrol atau tingkah laku yang dimiliki oleh sistem kontrol yang kompleks dalam multimedia pembelajaran yang dibuat. Pada langkah ini terdapat tiga Langkah a) Memilih dan menetapkan aplikasi software yang digunakan, dalam pengembangan ini software yang digunakan adalah Microsoft office 365, yang telah menerbitkan fitur baru pada Microsoft office 365 powerpoint yaitu morph dan zoom. b) Mengembangkan flowchart, hal ini dilakukan untuk menjelaskan, menggambarkan, dan menyederhanakan rangkaian prosedur dalam multimedia interaktif yang dikembangkan. Dari media pembelajaran di mulai (start) hingga selesai (end), alur-alur yang dibuat dapat dijelaskan di dalam flowchart. c) Merangcang storyboard, hal ini dilakukan untuk mengetahui dan menjelaskan tampilan yang ada dalam multimedia interaktif yang dikembangkan. Bentuk visualnya, audio, hingga struktur navigasi yang tersedia.

\section{Pengumpulan Bahan}

Pada langkah ini pengembang melakukan pengumpulan bahan yang sesuai dengan kebutuhan yang dikerjakan. Bahanbahan tersebut, antara lain dengan gambar clip art, foto, animasi, audio, dan lain-lain yang diperlukan pada langkah berikutnya yaitu langkah pembuatan (assembly). Pengumpulan materi pokok dilakukan dengan menggunakan buku terbitan Intan Pariwara mata pelajaran Matematika kelas VII yang digunakan oleh SMP Negeri 55 Surabaya, sedangkan pengumpulan gambar, video, dan audio diperoleh melalui pembuatan sendiri ataupun mengunduh melalui internet.

\section{Pembuatan}

Pada langkah ini dilakukan pembuatan semua objek atau bahan multimedia dengan kata lain yaitu pengkodingan atau pembuatan multimedia 
pembelajaran interaktif. Pembuatan media ini harus didasarkan pada langkah perancangan (design) dan menggunakan media-media yang telah dikumpulkan pada langkah pengumpulan bahan (material collecting) dengan menggunakan software Microsoft office 365 power point. Semua bahan yang sudah dikumpulkan kemudian disatukan dalam desain yang telah dirancang dengan menggunakan software Microsoft office 365 powerpoint.

\section{Uji coba}

Hal ini dilakukan setelah menyelesaikan langkah pembuatan dengan menjalankan multimedia interaktif dan melihat apakah ada kesalahan atau tidak. Fungsi dari langkah ini adalah melihat hasil pembuatan media apakah sesuai dengan yang diharapkan atau tidak. Langkah pengujian terdiri dari tiga yaitu uji coba ahli, uji coba teman sejawat dan uji coba kelompok kecil. Langkah uji coba ahli dilakukan oleh ahli media dan ahli materi, jika dalam proses uji coba masih terdapat saran untuk melakukan perubahan maka media akan direvisi, apabila dari hasil uji coba media dan materi tersebut memenuhi kriteria kelayakan maka akan dilanjutkan melakukan uji coba kelompok kecil yang dilakukan oleh pengguna multimedia pembelajaran yaitu siswa SMP Negeri 55 Surabaya.

Subjek uji coba produk penelitian pengembangan ini adalah peserta didik (kelompok kecil), teman sejawat (guru), dan para ahli. Subyek uji coba kelompok kecil berjumlah 12 orang peserta didik kelas VII SMP Negeri 55 Surabaya. Alasan peng-ambilan kelompok kecil sebanyak 12 orang, karena hal ini sesuai dengan (Dick and Carey, 2001: 291) bahwa jumlah yang diperlukan dalam evaluasi kelompok kecil hanya terdiri dari delapan sampai dengan dua puluh orang.

Jenis data pada penelitian ini adalah berbentuk kualitatif. Instrumen digunakan adalah angket atau kuesioner. Kuesioner (Angket) merupakan teknik pengumpulan data yang dilakukan dengan cara memberi seperangkat pertanyaan atau pernyataan tertulis kepada responden untuk dijawabnya (Sugiyono, 2015). Uji coba ahli dan teman sejawat dilakukan langsung kepada ahli dengan memberikan intrument penilaian dan produk yang dikembangkan. Pembagian angket responden dilakukan di dalam kelas setelah peserta didik menggunakan multimedia pembelajaran yang dikembangkan. Aturan pemberian skor untuk uji coba ahli dan teman sejawat dapat dilihat pada tabel berikut.

Tabel 1. Aturan Pemberian Skor Butir Instrumen Ahli dan Teman Sejawat

\begin{tabular}{ccc}
\hline Penilaian & Keterangan & Skor \\
\hline SB & Sangat Baik & 5 \\
B & Baik & 4 \\
C & Cukup & 3 \\
KB & Kurang Baik & 2 \\
SK & Sangat Kurang Baik & 1 \\
\hline
\end{tabular}

Tabel 2. Aturan Pemberian Skor Butir Instrumen Responden

\begin{tabular}{ccc}
\hline Penilaian & Keterangan & Skor \\
\hline SS & Sangat Setuju & 5 \\
S & Setuju & 4 \\
N & Netral & 3 \\
TS & Tidak Setuju & 2 \\
STS & Sangat Tidak Setuju & 1 \\
\hline \multicolumn{2}{c}{ (Fakhriyannur, 2017) }
\end{tabular}

Penganalisisan data instrumen menggunakan skala likert. Langkahlangkah dalam menganalisis data yang diperoleh menggunakan analisis deskriptif yaitu sebagai berikut Widoyoko (2013)
Menghitung nilai rata-rata skor tiap-tiap indikator instrument. Menghitung nilai ratarata skor total masing-masing aspek penilaian. Membandingkan nilai rata-rata skor total masing-masing aspek penilaian 
dengan kriteria yang telah ditentukan. Ketentuan konversi data kuantitatif menjadi kualitatif dan rentang skor penilaian ahli materi, ahli media, teman sejawat dan responden dapat dilihat pada tabel berikut.

Tabel 3. Pedoman Konversi Skor Uji Coba

\begin{tabular}{cc}
\hline Rentang Skor & Kategori \\
\hline $4,206<\mathrm{X}$ & Sangat Baik \\
$3,402<\mathrm{X} \leq 4,206$ & Baik \\
$2,598<\mathrm{X} \leq 3,402$ & Cukup Baik \\
$1,794<\mathrm{X} \leq 2,598$ & Kurang Baik \\
$\mathrm{X} \leq 1,794$ & Tidak Baik \\
\hline & (Widoyoko, 2013)
\end{tabular}

\begin{abstract}
Kemudian, menentukan nilai keseluruhan aspek penilaian setiap pengujian dengan menghitung skor rata-rata seluruh aspek penilaian kemudian diubah sesuai dengan kriteria. Untuk mengetahui kualitas berdasarkan penilaian dalam bentuk persentase menggunakan rumus di bawah ini.
\end{abstract}

\section{Rumus Index \% $\mathrm{Ts} / \mathrm{X} \times 100 \%=\mathrm{P}$}

Keterangan,

$\mathrm{P}$ : Persentase

Ts : Total Skor

$\mathrm{X}$ : Skor tertinggi dikali total skor respons keseluruhan

\section{Rumus Interval}

$\mathrm{I}=100 /$ Jumlah Skor (Likert)

Maka, $\mathrm{I}=100 / 5=20$

Jadi, Interval jarak dari terendah 0\% hingga tertinggi $100 \%$ adalah 20 .

Tabel 4. Kriteria Interpretasi Skor

\begin{tabular}{cc}
\hline Persentase & Kriteria \\
\hline $0 \%-20 \%$ & Sangat Tidak Baik \\
$21 \%-40 \%$ & Tidak Baik \\
$41 \%-60 \%$ & Cukup Baik \\
$61 \%-80 \%$ & Baik \\
$81 \%-100 \%$ & Sangat Baik \\
\hline
\end{tabular}

\section{Distribusi}

Langkah terakhir, melakukan distribusi, pada tahap ini akan dilakukan implementasi serta evaluasi terhadap media dan setelah semuanya selesai. Media pembelajaran akan dijalankan melalui komputer dan LCD. Distribusi multimedia yang dikembangkan, dengan melakukan penyimpanan multimedia dalam bentuk Compact Disk (CD). Beberapa tahap implementasi dan evaluasi yang pengembang lakukan adalah a) spesifikasi perangkat keras dan perangkat lunak yang dibutuhkan untuk mengeksekusi media, b) cara pengoprasian multimedia pembelajaran yang dikembangkan, c) menjelaskan hasil tampilan, dan d) Penyebarluasan produk. Pengembang juga menyediakan buku pendamping untuk peserta didik belajar di rumah. Setelah penyimpanan, pengembang melakukan pendistribusian multimedia ke guru dan peserta didik kelas VII SMP Negeri 55 Surabaya.

\section{HASIL DAN PEMBAHASAN}

Data hasil uji coba diperoleh setelah pengembang menyebarkan multimedia yang dikembangkan beserta angket kepada para responden yang terdiri dari ahli media, ahli materi (isi), rekan sejawat dan peserta didik kelas VII SMP Negeri 55 Surabaya. Multimedia pembelajaran yang disebarkan berupa buku panduan dan Compact Disk (CD) atau Flashdisk. Multimedia pembelajaran ini digunakan untuk membantu guru dan siswa dalam mempelajari materi Perbandingan. Sebelum membahas hasil penelitian yang diperoleh, penelitian ini menggunakan model Luther yang terdiri dari: 


\section{Konsep}

Langkah ini dilakukan untuk menentukan mata pelajaran, identifikasi mata pelajaran, merumuskan kompetensi dasar berdasarkan silabus dan kurikulum, menentukan tujuan media, serta menentukan konsep isi multimedia pembelajaran. Mata pelajaran yang dikembangkan adalah mata pelajaran Matematika SMP kelas VII materi Perbandingan. Adapun Langkah yang dilakukan yaitu: a) Identifikasi Mata Pelajaran, multimedia pembelajaran yang dikembangkan menggunakan materi Perbandingan, materi ini terdapat di kelas VII semester II SMP. Subbab materi perbandingan yang digunakan yaitu (1) rasio dan perbandingan, (2) perbandingan senilai dan skala, (3) perbandingan berbalik nilai, (4) membedakan perbandingan senilai dan berbalik nilai dengan menggunakan tabel data, grafik, dan persamaan, serta (5) penerapan perbandingan. Konsep yang digunakan untuk menjelaskan materi perbandingan yang disajikan meliputi ilustrasi gambaran perbandingan, gambargambar yang berkaitan dengan materi perbandingan, video dan game education. b) Merumuskan Kompetensi Dasar, pengembang merumuskan kompetensi dasar berdasarkan silabus dan kurikulum yang digunakan, Adapun kompetensi dasar tersebut adalah (1) 3.7 menjelaskan rasio dua besaran (satuannya sama dan berbeda), (2) 3.8 membedakan perbandingan senilai dan berbalik nilai dengan menggunakan tabel data, grafik, dan persamaan, (3) 4.7 menyelesaikan masalah yang berkaitan dengan rasio dua besaran (satuannya sama dan berbeda), serta (4) 4.8 menyelesaikan masalah yang berkaitan dengan perbandingan senilai dan berbalik nilai. c) Tujuan Multimedia Pembelajaran Interaktif, multimedia pembelajaran interaktif materi perbandingan ini ditujukan untuk peserta didik kelas VII SMP Negeri 55 Surabaya. Multimedia pembelajaran ini bertujuan untuk memudahkan guru menjelaskan materi perbandingan di dalam kelas, kedudukan multimedia pembelajaran ini sebagai media pendamping guru mengajar di dalam kelas dan media belajar/ pendalaman materi peserta didik di rumah, karena tersedia kuis yang dikemas dalam bentuk game education pada multimedia yang dikembangkan. Serta diharapkan peserta didik dapat dengan mudah memahami materi yang dijelaskan dan termotivasi untuk menyelesaikan evaluasi yang tersedia. d) Konsep Isi Multimedia Pembelajaran, multimedia pembelajaran interaktif menggunakan animasi morph dan zoom pada Microsoft office 365 materi perbandingan terdiri dari beranda (halaman awal), kompetensi dasar, tujuan pembelajaran, jendela materi perbandingan dan evaluasi yang dikemas dalam bentuk game education.

2. Desain

Design (Desain), pada langkah ini pengembang membuat spesifikasi secara rinci mengenai arsitektur proyek, serta gaya dan kebutuhan bahan untuk produk yang dibuat berdasarkan pada perancangan materi yang dimasukkan dalam multimedia pembelajaran. Pengembang memilih dan menetapkan aplikasi software yang digunakan adalah Microsoft office 365, yang telah menerbitkan fitur baru pada Microsoft office 365 powerpoint yaitu morph dan zoom. Kemudian membuat flowchart dan storyboard. Sebelum membuat flowchart dan storyboard, pengembang melakukan analisis materi. Hal ini dilakukan pengembang karena multimedia pembelajaran interaktif yang dikembangkan dibuat berdasarkan dari hasil analisis materi terhadap silabus dan kurikulum yang digunakan. 


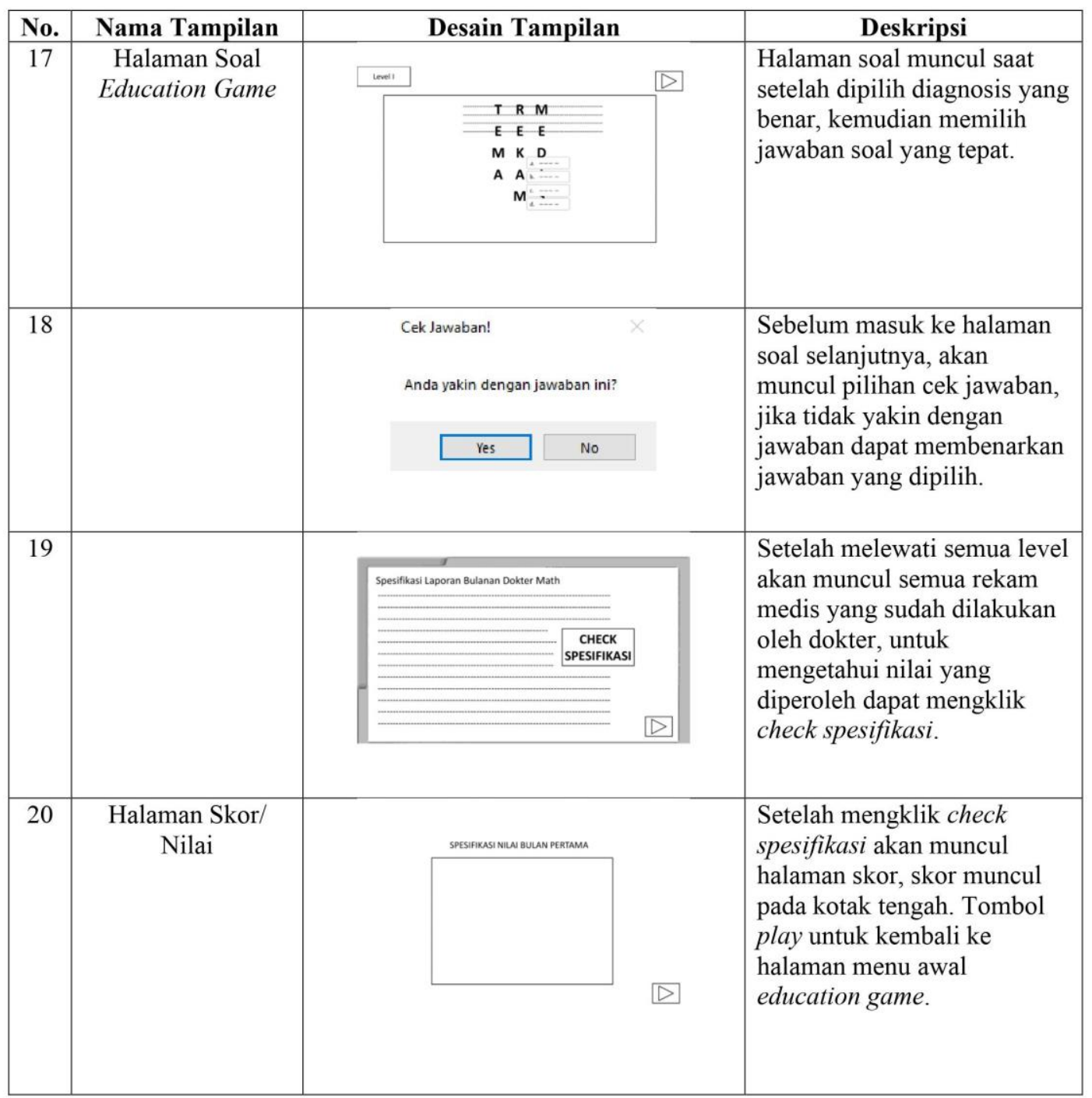

Gambar 2. Storyboard 5

3. Pengumpulan Bahan

Pada tahap ini dilakukan pengumpulan bahan materi yang sesuai dengan kebutuhan pembuatan media. Adapun bahan-bahan yang telah dikumpulkan oleh pengembang pada tahap ini, yaitu bahan-bahan materi pembelajaran kelas VII bab perbandingan dari buku PR Intan Pariwara, buku paket Tiga Serangkai, dan buku siswa matematika K13 2017. Gambar dan audio tombol navigasi penunjang multimedia sebagai bahan ilustrasi materi atau objek animasi pada multimedia pembelajaran interaktif. Video sebagai penjelas materi perbandingan. Audio sebagai music background pada multimedia pembelajaran.

\section{Pembuatan}

Tahap ini dilakukan pembuatan produk/ multimedia yang sesuai dengan flowchart dan storyboard yang telah dibuat dengan menggunakan semua bahan yang telah dikumpulkan pada tahap sebelumnya. Pembuatan multimedia ini diawali dengan menginstall terlebih dahulu aplikasi software Microsoft office 365. Jika software sudah terpasang dilanjutkan dengan mendesain tampilan slide demi slide di Microsoft office powerpoint 365 sebelumnya sudah berada pada tampilan lembar kerja baru powerpoint 365. Berikut salah satu tampilan jendela materi menggunakan transisi morph. 


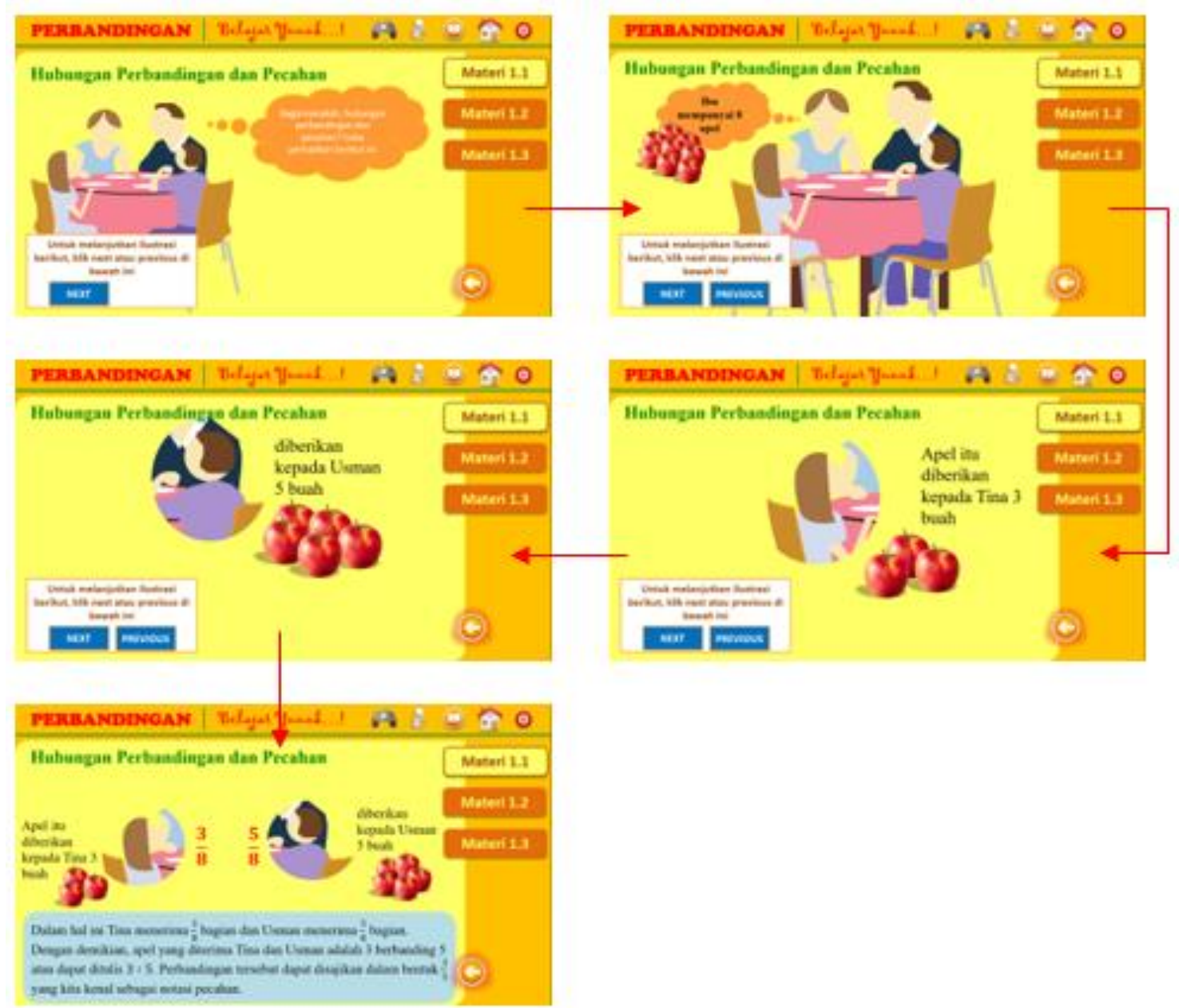

Gambar 3. Tampilan Menggunakan Morph

\section{Uji Coba}

Hasil uji coba yang telah dilakukan yaitu uji coba ahli, uji coba teman sejawat, dan uji coba kelompok kecil. Data hasil uji coba ahli materi diperoleh dari hasil pengisian instrumen angket oleh ahli materi. Instrumen ahli materi diberikan kepada dosen pengampu di bidangnya yang juga merupakan KAPRODI Pendidikan Matematika Universitas PGRI Adi Buana Surabaya. Instrumen yang diberikan berisi
20 butir nilai pernyataan, kolom saran, komentar, dan kesimpulan hasil penilaian. Kolom saran dan komentar merupakan acuan untuk dilakukannya perbaikan atau revisi sebelum media dilakukan uji coba kepada peserta didik (responden).

Data hasil uji coba yang dilakukan oleh ahli materi meliputi 2 aspek yaitu kandungan kognisi dan penyajian informasi. Data hasil uji coba ahli materi dapat dilihat pada tabel berikut.

Tabel 5. Data Hasil Penilaian Ahli Materi

\begin{tabular}{lcc}
\hline \multicolumn{1}{c}{ Keterangan Aspek } & Rata-rata & Kriteria \\
\hline Kandungan Kognisi & 4,75 & Sangat Baik \\
Penyajian Informasi & 4,91 & Sangat Baik \\
\hline Rata-rata Keseluruhan & $\mathbf{4 , 8 3}$ & Sangat Baik \\
\hline
\end{tabular}

Keseluruhan rata-rata yang diperoleh dari 20 butir pernyataan instrumen mendapat 4,83 di mana angka tersebut masuk dalam kategori sangat baik. Berdasarkan tabel data hasil uji coba ahli materi yang dinilai dari 2 aspek, selanjutnya 
dapat dilakukan perhitungan untuk mengetahui kualitas multimedia secara keseluruhan dalam bentuk persentase dengan hasil sebagai berikut.

$\mathrm{P}=\frac{\mathrm{Ts}}{\mathrm{X}} \times 100 \%$

$\mathrm{P}=\frac{(59+38)}{(5 \times 20)} \times 100 \%$

$\mathrm{P}=\frac{97}{100} \times 100 \%$

$\mathrm{P}=97 \%$

Adapun komentar dan saran yang diberikan oleh ahli materi yaitu sangat setuju dengan adanya penelitian pengembangan yang berkaitan dengan media pendamping yang dapat membantu siswa dalam memahami matematika agar lebih mudah siswa dalam menyerap materi yang diberikan oleh guru. Kesimpulan dari hasil instrumen yang dinilai oleh ahli materi bahwa multimedia pembelajaran interaktif menggunakan transisi morph dan zoom pada Power point Microsoft office 365 layak digunakan tanpa revisi.

Penilaian instrumen yang dilakukan oleh ahli media meliputi 4 aspek yaitu kemudahan navigasi, integrasi media, artistik dan estetika, serta fungsi keseluruhan. Produk pengembangan yang diserahkan kepada ahli media adalah buku panduan dan Compact Disk (CD-R) yang berisi tentang pengembangan multimedia pembelajaran interaktif yang telah disajikan. Hasil uji coba ahli media dapat dilihat pada tabel di bawah ini.

Tabel 6. Data Hasil Penilaian Ahli Media

\begin{tabular}{lcc}
\hline \multicolumn{1}{c}{ Keterangan Aspek } & Rata-rata & Kriteria \\
\hline Kemudahan Navigasi & 3,9 & Baik \\
Integrasi Media & 4 & Baik \\
Artistik dan Estetika & 3,5 & Baik \\
Fungsi Keseluruhan & 4,4 & Sangat Baik \\
\hline Rata-rata Keseluruhan & $\mathbf{3 , 9 5}$ & Baik \\
\hline
\end{tabular}

Berdasarkan data hasil penilaian ahli media meliputi 4 aspek yaitu kemudahan navigasi, integrasi media, artistik dan estetika, serta fungsi keseluruhan. Perhitungan data hasil penilaian ahli media dari aspek kemudahan navigasi mendapatkan rata-rata sebesar 3,87. Berdasarkan tabel pedoman konversi data angka 3,87 termasuk kategori baik, sedangkan untuk aspek integrasi media mendapatkan rata-rata sebesar 4 data ini lebih besar dari aspek kemudahan navigasi namun masih berada dalam kategori yang sama, artinya termasuk dalam kategori baik. Penilaian aspek yang lain seperti aspek artistik dan estetika mendapatkan 3,4 masuk dalam kategori baik dan untuk aspek fungsi keseluruhan mendapatkan nilai tertinggi sebesar 4,4 nilai tersebut masuk dalam kategori sangat baik. Kemudian, untuk keseluruhan rata-rata yang diperoleh dari 21 butir pernyataan instrumen mendapat nilai 3,95 di mana angka tersebut masuk dalam kategori baik. Pada saat uji coba ahli media, multimedia pembelajaran interaktif menggunakan transisi morph dan zoom pada powerpoint Microsoft office 365 ini layak digunakan dengan revisi kecil.

Berdasarkan tabel data hasil uji coba ahli media, selanjutnya dapat dilakukan perhitungan untuk mengetahui kualitas multimedia secara keseluruhan dalam bentuk persentase, hasil yang diperoleh sebesar 78,1\%. Adapun komentar dan saran yang diberikan oleh ahli media yaitu sebagai berikut:

1. Dibuat autoplay tanpa mencari file aplikasi

2. Ada kontras antara background dan font sehingga saat membaca tidak terlalu buram

3. Jika untuk pembelajaran mandiri ada baiknya tersedia tombol volume/ pilihan lagu karena karakter pembelajar berbeda.

4. Media sudah OK secara keseluruhan hanya ada perbaikan minor terkait pengoperasian awal dan pengaturan warna secara keseluruhan.

5. Beri kemasan yang baik pada media (CD-R), sebagaimana siap digunakan untuk pembelajaran. 
Kesimpulan dari hasil instrument yang dinilai oleh ahli media bahwa multimedia pembelajaran interaktif menggunakan transisi morph dan zoom pada Power point Microsoft office 365 layak digunakan dengan revisi kecil.

Uji coba teman sejawat penelitian pengembangan ini adalah Wakil Kepala SMP Negeri 1 Sugio Lamongan, selaku guru mata pelajaran Matematika SMP. Uji coba teman sejawat dilakukan setelah melakukan uji coba kepada ahli dan telah dilakukan revisi. Hasil uji coba teman sejawat mem-peroleh nilai dengan rata-rata keseluruhan sebesar 4,75, masuk dalam kategori Sangat Baik dengan persentase sebesar 95\%. Adapun komentar dan saran yang diberikan oleh teman sejawat yaitu media komunikasi pembelajaran yang efektif dan kredibel untuk materi pembelajaran, peserta didik memperoleh visualisasi lengkap dengan media power point dari office 365 dan semua dapat dibangun melalui contoh lewat internet yang sudah disediakan alamatnya. Pembelajaran dapat ditingkatkan secara terorganisasi dan mengakomodasi pada penyelenggaraan program pembelajaran secara keseluruhan materi yang dirancang secara multimedia dan dinamis.

Uji coba responden dilakukan pada peserta didik kelas VII SMP Negeri 55 Surabaya, uji coba ini tergolong uji coba kelompok kecil, yang diikuti sebanyak 12 orang peserta didik. Penelitian ini bertujuan untuk mengevaluasi respons siswa terhadap multimedia yang dikembangkan dan untuk mengetahui kelayakan multimedia pembelajaran interaktif menggunakan transisi morph dan zoom pada power point microsoft office 365. Penilaian yang diberikan responden meliputi 5 aspek yaitu kandungan kognisi, penyajian informasi, kemudahan navigasi, artistik dan estetika, fungsi keseluruhan. Hasil uji coba ahli media dapat dilihat pada tabel berikut.

Tabel 7. Data Hasil Penilaian Responden

\begin{tabular}{lcc}
\hline \multicolumn{1}{c}{ Keterangan Aspek } & Rata-rata & Kriteria \\
\hline Kandungan Kognisi & 4,02 & Baik \\
Penyajian Informasi & 3,97 & Baik \\
Kemudahan Navigasi & 4,04 & Baik \\
Artistik dan Estetika & 4,33 & Sangat Baik \\
Fungsi Keseluruhan & 4,15 & Baik \\
\hline Rata-rata Keseluruhan & $\mathbf{4 , 1 0}$ & Baik \\
\hline
\end{tabular}

Responden untuk uji coba kelompok kecil adalah peserta didik kelas VII SMP Negeri 55 Surabaya. Berdasarkan data hasil penilaian uji coba kelompok kecil (responden) meliputi 5 aspek yaitu kandungan kognisi, penyajian informasi, kemudahan navigasi, artistik dan estetika, serta fungsi keseluruhan. Perhitungan data hasil penilaian 12 responden dari aspek kandungan kognisi memperoleh rata-rata sebesar 4,02 termasuk kategori baik, aspek penyajian informasi diperoleh rata-rata sebesar 3,97 masuk dalam kategori baik. Kemudian, untuk aspek kemudahan navigasi mendapatkan rata-rata sebesar 4,04 termasuk kategori baik, sedangkan untuk aspek artistik dan estetika mendapatkan nilai tertinggi sebesar 4,33 di mana angka tersebut masuk dalam kategori sangat baik dan untuk aspek fungsi keseluruhan diperoleh 4,15 nilai tersebut masuk dalam kategori baik. Kemudian, untuk keseluruhan rata-rata yang diperoleh dari 20 butir pernyataan instrumen mendapat nilai 4,10 di mana angka tersebut masuk dalam kategori baik.

Berdasarkan tabel data hasil uji coba responden yang dinilai dari 5 aspek, selanjutnya dapat dilakukan perhitungan untuk mengetahui kualitas multimedia secara keseluruhan dalam bentuk persentase dengan hasil sebagai berikut.

$$
\begin{aligned}
& P=\frac{T s}{X} \times 100 \% \\
& P=\frac{193+286+194+104+199}{20 \times 5 \times 12} \times 100 \% \\
& P=\frac{976}{1200} \times 100 \% \\
& P=81,33 \%
\end{aligned}
$$


Persentase hasil data yang didapat untuk mengetahui kualitas multimedia sebesar $81,33 \%$, angka tersebut masuk dalam kategori sangat baik. Sehingga multimedia pembelajaran interaktif ini layak digunakan untuk mendukung kegiatan pembelajaran peserta didik kelas VII SMP Negeri 55 Surabaya.

Sebagai produk multimedia pembelajaran interaktif menggunakan transisi morph dan zoom pada powerpoint office 365 ini memiliki kelebihan dan kekurangan. Kelebihannya multimedia ini memberikan visualisasi materi dari hasil penggunaan transisi morph dan zoom yang memudahkan guru menjelaskan materi perbandingan di dalam kelas dan multimedia ini menggunakan visual basic untuk pembuatan soal evaluasi yang sifatnya dinamis. Kekurangannya adalah efek animasi akan terhenti sampai transisi morph selesai. Namun, untuk mengatasi hal ini dapat dilakukan dengan menggunakan efek animasi pengganti yang sesuai.

\section{SIMPULAN}

Berdasarkan data hasil uji coba dan analisis data pengembangan tentang multimedia pembelajaran interaktif menggunakan transisi morph dan zoom dapat disimpulkan bahwa setelah peserta didik menggunakan multimedia ini, peserta didik dapat lebih mudah memahami materi perbandingan, karena peserta didik memperoleh visualisasi lengkap dan semua dapat dibangun melalui contoh lewat internet yang sudah disediakan alamatnya. Multimedia pembelajaran ini mampu meningkatkan pembelajaran secara terorganisasi dan mengakomodasi pada penyelenggaraan program pembelajaran, karena keseluruhan materi yang dirancang secara multimedia dan dinamis. Kelayakan multimedia pembelajaran ini masuk kategori sangat baik dari hasil uji coba ahli materi, uji coba teman sejawat, dan uji coba responden. Sedangkan untuk hasil uji coba ahli multimedia ini masuk dalam kategori baik. Sehingga multimedia pembelajaran interaktif menggunakan transisi morph dan zoom materi perbandingan layak digunakan untuk mendukung kegiatan pembelajaran peserta didik kelas VII SMP Negeri 55 Surabaya.

\section{DAFTAR RUJUKAN}

Arsyad, A. (2002). Multimedia Interaktif Untuk Pembelajaran Multimedia. Jakarta: Rajawali Pers.

Astari, P. Y., Tastra, I. K., \& Sudhita, I. R. (2016). Pengembangan Multimedia Presentasi Pembelajaran Berorientasi Pembelajaran Kontekstual Untuk Meningkatkan Hasil Belajar IPA Kelas V Semester Genap Di SDN 2 Banjar Bali Singaraja Tahun Pelajaran 2015/2016. Jurnal Edutech Undiksha, 4, 1-10. doi: http://dx.doi.org/10.23887/jeu.v4i2.7 620

Binanto, I. (2010). Multimedia Digital Dasar Teori dan Pengembangannya. Yogyakarta: Andi.

Brata, D. N. P., dkk. (2020). Developing Pancasila and Civic Education (PPKn) based on local wisdom. Humanities \& Social Sciences Reviews, 8(1), 768-773. Doi

https://doi.org/10.18510/hssr.2020.8 192.

Darmawan, D. (2017). Teknologi Pembelajaran. Bandung: Remaja Rosdakarya.

Daryanto. (2013). Inovasi Pembelajaran Efektif. Bandung: Yrama Widya.

Degeng, I. N. (2018). Ilmu Pembelajaran Klasifikasi Variabel untuk Pengembangan Teori dan Penelitian. Yogyakarta: Yayasan Taman Pustaka Kristen Indonesia.

Depdiknas. (2003). Undang-Undang RI No. 20 Tentang Sistem Pendidikan Nasional. Jakarta: Depdiknas.

Dick. W, C. (2001). The Systematic Design of Instruction . Boston: AddisonWesley Educational Publisher Inc. 
Fakhriyannur. (2017). Pengembangan Media Pembelajaran Interaktif Teknik Animasi 2 Dimensi Berbasis Adobe Flash untuk Siswa Kelas XI Multimedia di SMK Muhammadiyah 1 Yogyakarta. Yogyakarta: UNY.

Hasanudin, C. (2017). Media Pembelajaran: Kajian Teoritis dan Kemanfaatan. Yogyakarta: Deepublish Publisher.

Kustianah, Mustaji, \& Walujo, D. A. (2019, April). Pengembangan Perangkat Pembelajaran Matematika Berbasis Multimedia Pada Materi Program Linear Untuk SMK Kelas XI. Education and Development Journal, 7(2), 128-135. doi:https://doi.org/10.37081/ed.v7i2. 910.

Mayasari, N., Hasanudin, C., \& Fitrianingsih, A. (2020). The use of wingeom software in geometry subject, how is the learning outcomes of junior high school students? Journal of Physics: Conference Series, 1477(4), 1-6. Doi https://doi.org/10.1088/17426596/1477/4/042042.

Suartama, I. K. (2012). Konsep Dasar Multimedia. Singaraja: Universitas Pendidikan Ganesha.

Sugiyono. (2015). Metode Penelitian Pendidikan Pendekatan Kuantitatif, Kualitatif, dan $R \& D$. Bandung: Alfabeta.

Suherman, E., \& dkk. (2003). Strategi Pembelajaran Kontemporer. Bandung: JICA.

Susilo, O. S., Degeng, I. S., \& Susilaningsih. (2017, Oktober). Pengembangan Multimedia Interaktif IPA Kelas V SD Pokok Bahasan
Organ Tubuh Manusia dan Hewan. Edcomtech Journal, 2, 161-166.

Yusuf, M. F., Toenlioe, A., \& Wedi, A. (2017, April). Pengembangan Multimedia Pembelajaran Interaktif IPA Materi Atmosfer Bumi Kelas VIII SMPN 3 Tulungagung. Edcomtech Journal, 2, 37-40.

Istiqlal, M. (2017). Pengembangan Multimedia Interaktif Dalam Pembelajaran Matematika. JIPMat. https://doi.org/10.26877/jipmat.v2i1. 1480

Widoyoko, E. P. (2013). EVALUASI PROGRAM PEMBELAJARAN (Instructional Program Evaluation). Jurnal Cakrawala Pendidikan. https://doi.org/10.21831/cp.v5i1.126 6 